\title{
Orally Administered Whey Proteins Have Comparable Effect on C-Peptide Secretion in Healthy Subjects as Standard C-Peptide Stimulation Tests
}

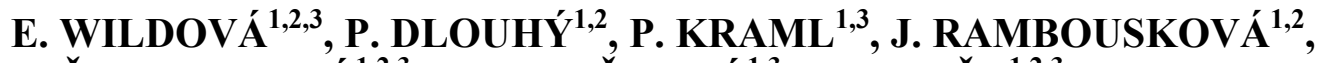 \\ V. ŠMEJKALOVÁ ${ }^{1,2,3}$, J. POTOČKOVÁ ${ }^{1,3}$, M. ANDĚL ${ }^{1,2,3}$ \\ ${ }^{1}$ Center for Research of Diabetes, Metabolism and Nutrition, Third Faculty of Medicine, Charles \\ University, Prague, Czech Republic, ${ }^{2}$ Department of Nutrition, Third Faculty of Medicine, Charles \\ University, Prague, Czech Republic, ${ }^{3}$ Second Department of Internal Medicine University Hospital \\ Královské Vinohrady and Third Faculty of Medicine, Prague, Czech Republic
}

Received September 4, 2012

Accepted November 9, 2012

On-line December 13, 2012

\section{Summary}

Our study compared total C-peptide secretion after administration of whey proteins and whey proteins in combination with glucose with results of classical tests assessing beta cell function in the pancreas of healthy individuals. Eight young, healthy (7 males, 1 female; aged 20-26 years), nonobese (BMI: $17-25.9 \mathrm{~kg} / \mathrm{m}^{2}$ ) participants with normal glucose tolerance underwent six C-peptide secretion tests. Three secretion tests measured C-peptide response to orally administered substances: whey proteins only (OWT), whey proteins with glucose (OWGT) and glucose only (OGTT); while three secretion tests measured $C$-peptide response to intravenously administered substances: arginine (AST), glucagon (GST) and glucose (IVGTT). OWT stimulated a greater (93\%, $\mathrm{p}<0.05)$ C-peptide response than AST and a $64 \%$ smaller response $(p<0.05)$ than OGTT. OWT also showed lower variability $(p<0.05)$ in $C$-peptide responses compared to OWGT and OGTT. The greatest total C-peptide response was induced by OWGT (36\% higher than glucose). OWT consistently increased C-peptide concentrations with lower individual variability, while insignificantly increasing glucose levels. Results of this study suggest that both dietology and beta-cells capacity testing could take advantage of the unique property of whey proteins to induce C-peptide secretion.

\section{Key words}

Whey proteins $\bullet$ Pancreatic beta cell capacity tests $\bullet$ C-peptide • Blood glucose $\bullet$ Healthy

\section{Corresponding author}

E. Wildová, Center for Research of Diabetes, Metabolism and Nutrition, Ruská 2411/ 87, Prague, CZ 100 00, Czech Republic. E-mail: elena.wildova@lf3.cuni.cz

\section{Introduction}

It has been well established that ingested dietary proteins are the physiological stimuli for insulin secretion and have potential to decrease the plasma glucose levels in healthy individuals (Floyd et al. 1966). The magnitude of the insulin response to ingestion of different doses and types of proteins varies; however, whey proteins have unique insulinotropic property (Nilsson et al. 2004, Pal and Ellis 2010).

Krezowski et al. (1986) showed that, in healthy individuals, an acute oral administration of $50 \mathrm{~g}$ of protein from lean beef in combination with glucose resulted in a non-synergic increase in serum insulin and C-peptide release - the incremental area under the curve (iAUC) was $28 \%$ higher than for glucose alone - and reduced the total postprandial glucose response compared to equal amounts of glucose. An orally administered dose of protein given alone elicited a modest increase in insulin secretion (iAUC $=28 \%$ of the glucose response) and had almost no influence on fasting glucose levels. A similar metabolic response was observed in a study by Nilsson et al. (2004) after 
administration of $18.2 \mathrm{~g}$ of whey proteins in combination with carbohydrates in healthy subjects. The insulin iAUC for whey proteins plus a glucose mixture was $90 \%$ higher than the insulin iAUC of glucose alone. A study by Akhavan et al. (2010) focused primarily on the effect of pure whey proteins on food intake and pre- and post-meal satiety. However, this study did not examine the effect of whey proteins on insulin secretion over a sufficiently long period of time (Polonsky et al. 1988) for a complete evaluation of the total insulin secretion response following an orally administered stimulus.

Therefore we decided to evaluate the effect of pure whey proteins on C-peptide secretion (Polonsky and Rubenstein 1984) relative to C-peptide secretion after glucose only. Furthermore, we focused on the comparison between total C-peptide secretion after pure whey proteins administration and total C-peptide secretion after whey proteins administration in combination with glucose, relative to other insulin secretion tests. These tests are based on intravenous administration (Chaillous et al. 1996) of glucose, arginine and glucagon and the oral administration of glucose (Small et al. 1985). These tests are currently used in research studies rather then in clinical practice. Since the tests ascertain the maximum C-peptide secretion capacity of the subject's pancreatic beta cells (Chaillous et al. 1996), these data can be used to assess the insulinotropic effect of whey proteins and its possible use in clinical practice.

\section{Subjects and Methods}

\section{Subjects}

Eight healthy young non-obese (body mass index (BMI), range: 17-25.9 $\mathrm{kg} / \mathrm{m}^{2}$ ) Caucasian subjects (7 men and 1 woman aged 20-26 years) were enrolled in this study. None of the participants were taking any drugs or supplements known to interference with insulin secretion or carbohydrate metabolism. All subjects were in generally good health, with no signs or symptoms of any acute or chronic diseases and no indications of lactose malabsorption.

After evaluation, participants were found to have no disorders of glucose metabolism (based on standard diagnostic criteria expressed in the ADA Expert Committee report (Genuth et al. 2003). Five participants ( 1 female and 4 males) had BMIs under $24.9 \mathrm{~kg} / \mathrm{m}^{2}$; the other three males had BMIs (range) of $25.4-25.9 \mathrm{~kg} / \mathrm{m}^{2}$. None of the subject had any signs of insulin resistance or any condition associated with insulin resistance (e.g. hypertension, dyslipidemia, polycystic ovary syndrome or acanthosis nigricans); all participants had normal insulin sensitivity index $463 \pm 22 \mathrm{ml} \mathrm{min}^{-1} \mathrm{~m}^{-2}$ (Mari et al. 2001), which correlated well with the homeostasis model assessment index (Matthews et al. 1985).

The study protocol was designed in accordance to the principles of the Helsinki Declaration and received prior approval by the Ethics Committee of the Third Faculty of Medicine, Charles University, Prague, Czech Republic. All participants were fully informed and gave written consent.

\section{Tests}

We used a controlled cross-over study design to evaluate the effect of whey proteins on the concentration of serum C-peptide and plasma glucose. All participants were tested on 6 different occasions in random order within a one month period. The tests were carried out in the research unit of the Second Department of Internal Medicine at University Hospital Královské Vinohrady, Prague, Czech Republic.

We used three intravenous tests to evaluate C-peptide secretion (Chaillous et al. 1996): the glucosedependent arginine-stimulation test (AST), the glucagon stimulation test (GST) and the intravenous glucose tolerance test (IVGTT). For the AST, $5 \mathrm{~g}$ of arginine in $50 \mathrm{ml}$ of $0.9 \%$ saline (Ardeapharma, Ševětín, Czech Republic) were injected as a bolus within $45 \mathrm{~s}$. In case of the GST, $2 \mathrm{mg}$ of glucagon (Novo Nordisk, Bagsvaerd, Denmark) in $60 \mathrm{ml}$ of $0.9 \%$ saline were injected as a bolus within $60 \mathrm{~s}$. Finally for the IVGTT; bolus of $0.5 \mathrm{~g}$ per $\mathrm{kg}$ of body weight of glucose (using Glucose-30 solution, B/Braun, Melsungen, Germany) was injected within $3 \mathrm{~min}$.

The other three tests for C-peptide secretion evaluation were based on the oral administration of glucose alone (oral glucose tolerance test (OGTT), whey proteins alone (oral whey proteins test (OWT) and whey proteins in combination with glucose (oral whey proteins in combination with glucose test (OWGT). Substances used in these tests were administered in the form of drinks and were consumed within $3 \mathrm{~min}$. The OGTT was performed using a $75 \mathrm{~g}$ oral glucose load (Glukopur; Natura, Hamry u Havlíčkova Brodu, Czech Republic) in $300 \mathrm{ml}$ of water (Small et al. 1985). OWT substance consisted of $40 \mathrm{~g}$ of flavored whey proteins (Volactive UltraWhey80 (WPC80); DVN, Hoogeveen, the Netherlands) in $300 \mathrm{ml}$ water and OWGT substance 
consisted of $40 \mathrm{~g}$ of flavored whey proteins (Volactive UltraWhey80 (WPC80); DVN, Hoogeveen, the Netherlands) and $72.6 \mathrm{~g}$ of glucose (Glukopur; Natura, Hamry u Havlíčkova Brodu, Czech Republic) in $300 \mathrm{ml}$ water. OWGT had an equivalent amount of carbohydrate $(75 \mathrm{~g})$ as OGTT. OGTT and IVGTT results were used as reference values for their respective category (oral vs. intravenous).

All the tests were performed regularly at 8 a.m. after an overnight fast (at least $12 \mathrm{~h}$ ), except water. Before the tests, participants had unrestricted stable diets (at least $150 \mathrm{~g}$ of carbohydrate per day); a minimum of 3 days/week of physical activity was encouraged. Participants were non-smokers and agreed to abstain from alcohol and coffee consumption during the study period. All participants underwent all 6 tests.

A peripheral venous catheter connected with a three-way stopcock was inserted into the antecubital vein using aseptic technique. This set-up enabled intravenous access for the purpose of intravenous stimulation tests and for obtaining samples of venous blood; it also ensured standardized sampling conditions. After stopcock adjustment the same catheter was used for bolus injections and sampling (Gottsäter et al. 1992). The catheter was flushed with $0.9 \%$ saline after each blood sample and after administration of intravenous C-peptide stimulants (arginine, glucagon, glucose). The participants rested quietly on beds during the tests.

\section{Whey proteins}

The study employed whey protein concentrate 80 (Volactive UltraWhey80 (WPC80); DVN, Hoogeveen, the Netherlands) from a sweet cheese whey source containing $81 \%$ high-quality nutritional whey proteins, $6 \%$ lactose, $6 \%$ fat, $4 \%$ moisture and $3 \%$ minerals. $100 \mathrm{~g}$ of WPC 80 had an energy value of 1549 $\mathrm{kJ}$ or $362 \mathrm{kcal}$. Average proportion of branched chain amino acids (BCAA) in the whey proteins was (according to the manufacturer) $23 \%$; however our analysis using capillary electrophoresis and the HP3DCE system (Agilent Technologies, Waldbronn, Germany) showed a BCAA percentage of only $17.5 \%$.

Powdered whey proteins were administered as a protein drink flavored with $0.05 \mathrm{~g}$ of low-calorie aspartame (NutraSweet: The NutraSweet Company, Chicago, USA), $0.4 \mathrm{~g}$ of strawberry aroma AFFRAI 0005 (RJP International, Prague, Czech Republic) and $0.4 \mathrm{~g}$ of vanilla extract (RAPS-CZ, Prague, Czech Republic).

\section{Blood samples}

Fasting values of plasma glucose and serum C-peptide were taken $10 \mathrm{~min}$ after the catheter was inserted and $10 \mathrm{~min}$ before administration of secretagogues (time: -10 ). For the intravenous agents the first venous blood samples were obtained immediately after intravenous stimuli administration (time: 0) (Ward et al. 1984). For the oral tests, the first blood sample was taken at $30 \mathrm{~min}$; additional samples were taken at 60, 90, 120, 150 and $180 \mathrm{~min}$. For the AST and GST, the sampling times were $1 \mathrm{~min}, 3 \mathrm{~min}, 5 \mathrm{~min}, 7 \mathrm{~min}, 10 \mathrm{~min}$, $20 \mathrm{~min}$ and $30 \mathrm{~min}$ after administration; for the IVGTT, sampling times were $1 \mathrm{~min}, 3 \mathrm{~min}, 5 \mathrm{~min}, 7 \mathrm{~min}, 10 \mathrm{~min}$, $30 \mathrm{~min}, 60 \mathrm{~min}$ and $120 \mathrm{~min}$ after administration.

Venous blood samples of glucose and C-peptide were collected in a closed blood collection system (S-Monovette; Sarstedt, Nümbrecht, Germany). Glucose was drawn into tubes containing sodium fluoride, while blood for C-peptide testing was drawn into sample tubes without additives.

Blood samples for blood glucose determination were processed immediately after being drawn by the Department of Biochemistry and Pathobiochemistry, Third Faculty of Medicine and University Hospital Královské Vinohrady, Charles University in Prague, Czech Republic. Blood samples for C-peptide determination were immediately cooled on ice to $21{ }^{\circ} \mathrm{C}$ and then centrifuged for $15 \mathrm{~min}$ at $3000 \mathrm{G}$ (Jouan BR4i, DJB Labcare, Buckinghamshire, England). The samples then were frozen at $-80{ }^{\circ} \mathrm{C}$ for 32 days until actual laboratory analysis.

Plasma glucose concentrations were determined using the hexokinase method (Passey et al. 1977) by a Konelab Glucose analyzer (Thermo Fisher Scientific Oy, Vantaa, Finland). The detection limit was $0.1 \mathrm{mmol} / \mathrm{l}$.

Serum C-peptide concentrations were analyzed using a 2-site immunochemiluminometric assay (Kao et al. 1992) by an Immunolite 2000 immunoassay system (Diagnostic Products Corporation, Las Angeles, California, USA). The analytical range of the assay was $0.17-2.32 \mathrm{nmol} / 1$ and the lower limit of sensitivity was $0.017 \mathrm{nmol} / \mathrm{l}$. The inter- and intra-assay coefficients of variation $(\mathrm{CVs})$ were less than $6 \%$.

\section{Statistics}

To quantify the plasma glucose and the serum C-peptide responses relative to the test substances, the incremental area under the curve (iAUCs) was calculated using the trapezoidal rule and using the initial 
fasting value of the respective metabolite as the baseline (i.e. blood sample $\mathrm{t}=-10 \mathrm{~min}$ ). To allow fair comparisons among tests with different durations, iAUCs were further normalized by the test duration (iAUCs/min) according to Greenbaum et al. (2008). The statistical comparison between the total C-peptide response and plasma glucose level, relative to the reference was carried out using the two-sided t-test. Comparisons of C-peptide response variability between stimulation tests were carried out by a likelihood ratio test employing coefficients of variation described by Verrill and Johnson (2007).

All data in the text are presented as means \pm SEMs. All statistical hypotheses were tested at significance level 0.05 using MATLAB software (2011b, Mathworks, Natick, MA, USA).

\section{Results}

\section{C-peptide response (Fig. 1)}

The average fasting concentration of serum C-peptide was (mean \pm SEM) $0.43 \pm 0.02 \mathrm{nmol} / 1$. All oral tests resulted in a similar shape for the C-peptide response curve, with a peak at $30 \mathrm{~min}$. In case of OGTT (reference), the C-peptide concentration peaked at $1.61 \pm 0.39 \mathrm{nmol} / 1$ above baseline. The result of OWT and OWGT, relative to OGTT, was lower by $57 \%$ and higher by $63 \%$, respectively. Subsequent concentration decreases reached baseline within 120-180 min (OWT and OGTT) and after $180 \mathrm{~min}$ (OWGT). Individual C-peptide concentrations differences were lower $(\mathrm{p}<0.05)$ at 60 and $90 \mathrm{~min}$ in case of OWT than in case of OGTT. Following OWGT, the C-peptide concentration at $30 \min (p<0.05)$ was the only one, which was higher than OGTT.

IVGTT (reference) resulted in a peak C-peptide concentration of $1.56 \pm 0.17 \mathrm{nmol} / 1$ above baseline, which occurred $1 \mathrm{~min}$ after administration and lasted for $30 \mathrm{~min}$. AST peaked at value lower by $57 \%$ (3 min) compared to IVGTT, while GST produce almost (6 \% lower) the same maximum concentration as IVGTT. Subsequent concentration decreases reached baseline before $20 \mathrm{~min}$ (AST), after $30 \mathrm{~min}$ (GST) and after $120 \mathrm{~min}$ (IVGTT). Individual $\mathrm{C}$-peptide concentrations differences were lower $(\mathrm{p}<0.05)$ during the whole test period in case of AST compared to IVGTT. GST managed to maintain similar concentrations as IVGTT except for sample times 0 , 1 and $30 \mathrm{~min}$, where it was lower $(\mathrm{p}<0.05)$ than IVGTT.
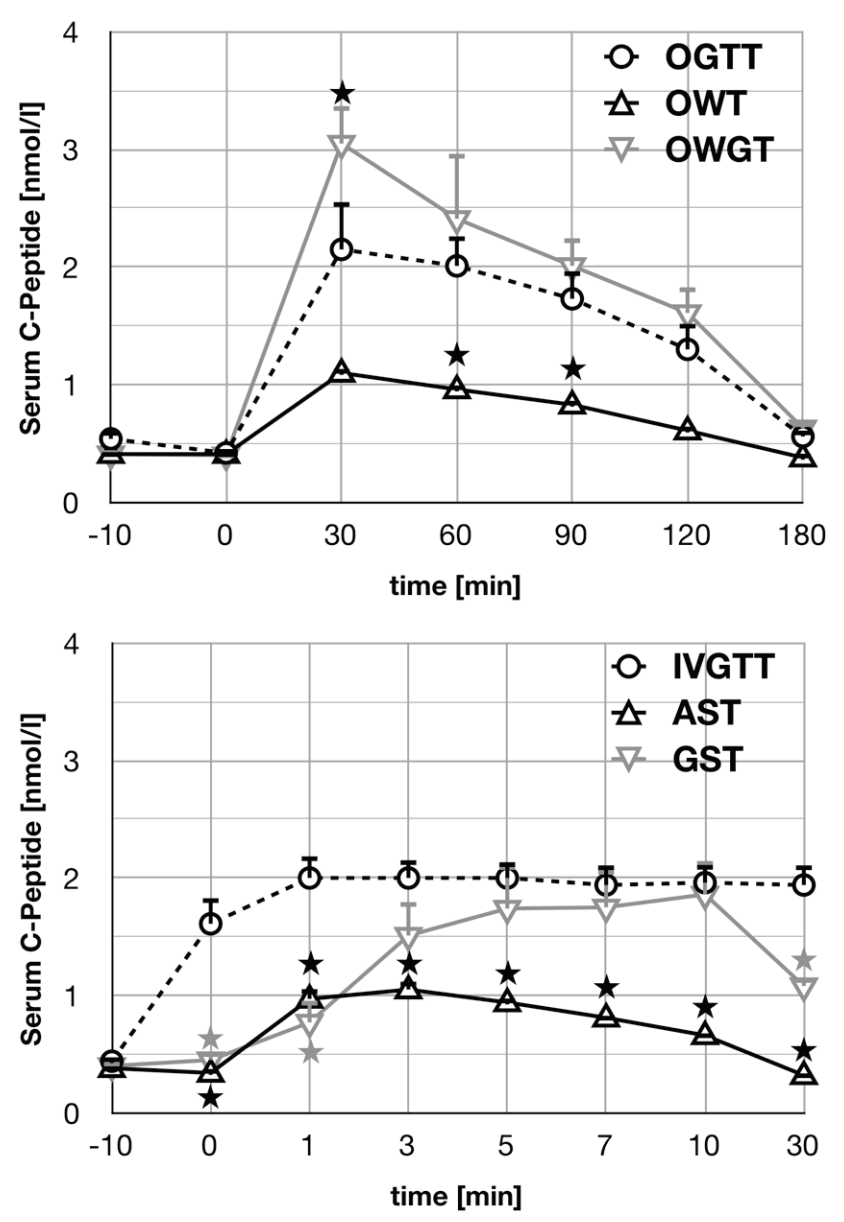

Fig. 1. Mean ( \pm SEM) values of serum C-peptide concentration in response to orally administered tests - OGTT (reference), OWT and OWGT - and intravenous tests - IVGTT (reference), AST and GST in healthy subjects $(n=8)$. * indicates values significantly different from the reference $(p<0.05)$.

\section{Glucose response (Fig. 2)}

The average fasting plasma glucose concentration (baseline) was (mean \pm SEM) 4.33 \pm 0.06 $\mathrm{mmol} / 1$. Performing OWGT and OGTT induced similar glucose response shaped curves over $60 \mathrm{~min}$ with peak concentrations (from baseline) occurring at $30 \mathrm{~min}$. The values steadily decreased until fasting concentrations were reached (between 90-120 min). OGTT showed glucose concentration peak at $2.25 \pm 0.24 \mathrm{mmol} / \mathrm{l}$ above baseline. Compared to OGTT, the glucose response was $25 \%$ lower after OWGT. OWT lowered glucose concentrations below fasting values for the entire $120 \mathrm{~min}$ observation period, the negative peak concentration value occurred at $60 \mathrm{~min}$ and was $13 \%$ lower than the fasting glucose value. Individual plasma glucose level differences were lower $(p<0.05)$ at 30 and $60 \mathrm{~min}$ in case of OWT relative to OGTT result. 

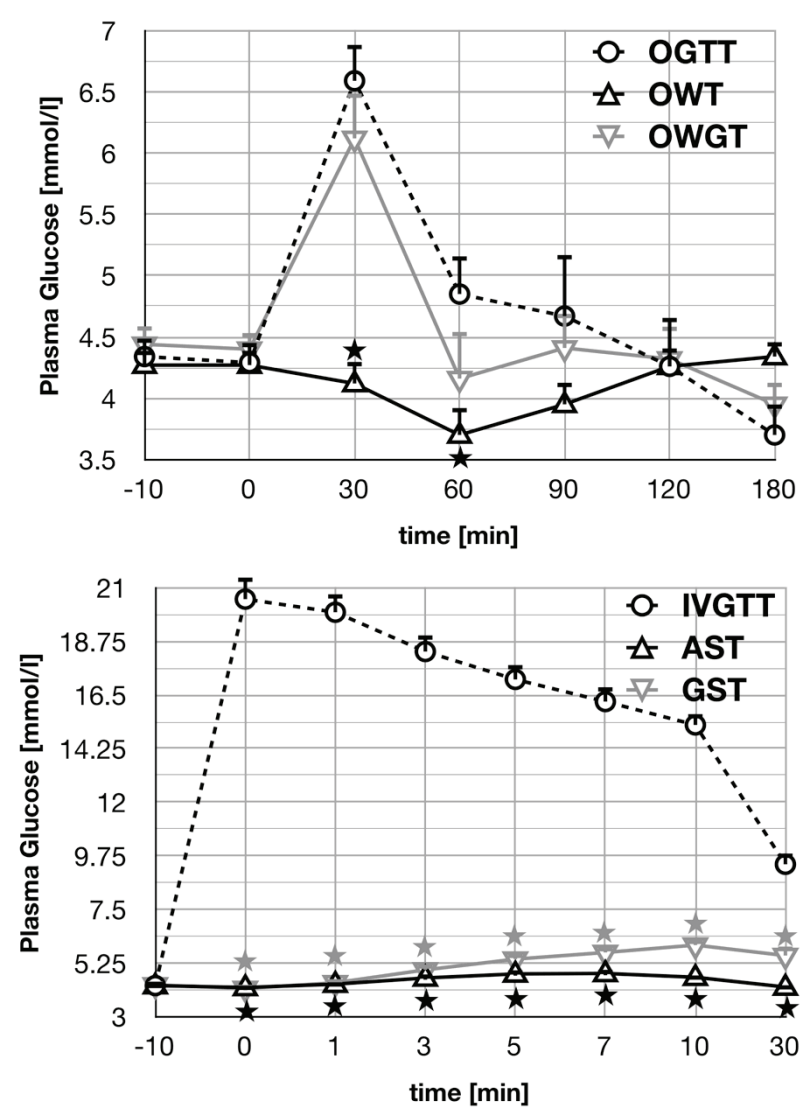

Fig. 2. Mean ( \pm SEM) values of plasma glucose concentration in response to orally administered tests - OGTT (reference), OWT and OWGT - and intravenous tests - IVGTT (reference), AST and GST in healthy subjects $(n=8) . *$ indicates values significantly different from the reference $(p<0.05)$.

The peak plasma glucose concentration, in case of IVGTT, was $16.23 \pm 0.92 \mathrm{mmol} / \mathrm{l}$ above baseline and occurred immediately after administration. AST and GST showed a peak value that was $97 \%$ lower $(7 \mathrm{~min})$ and $88 \%$ lower (20 $\mathrm{min})$, respectively, relative to IVGTT result. Subsequent concentration decreases reached baseline between 10 and $20 \mathrm{~min}$ (AST), after $30 \mathrm{~min}$ (GST) and between 60-120 min (IVGTT). Individual plasma glucose concentrations were lower $(\mathrm{p}<0.05)$ during the whole test period of both AST and GST relative to IVGTT.

\section{iAUC/min - C-peptide response (Fig. 3)}

Average C-peptide iAUC/min was (mean \pm SEM) $1.27 \pm 0.19 \mathrm{nmol} / 1$ and $1.00 \pm 0.10 \mathrm{nmol} / 1$ for OGTT and IVGTT, respectively. OWT induced an $\mathrm{iAUC} / \mathrm{min}$ value $64 \%$ lower $(\mathrm{p}<0.05)$ than OGTT (reference), as opposed to OWGT, that reached an $\mathrm{iAUC} / \mathrm{min}$ value $36 \%$ higher (compared to OGTT (reference). Furthermore for OWT, the variability of the iAUC/min $\mathrm{C}$-peptide response was lower $(\mathrm{p}<0.05)$ than in case of

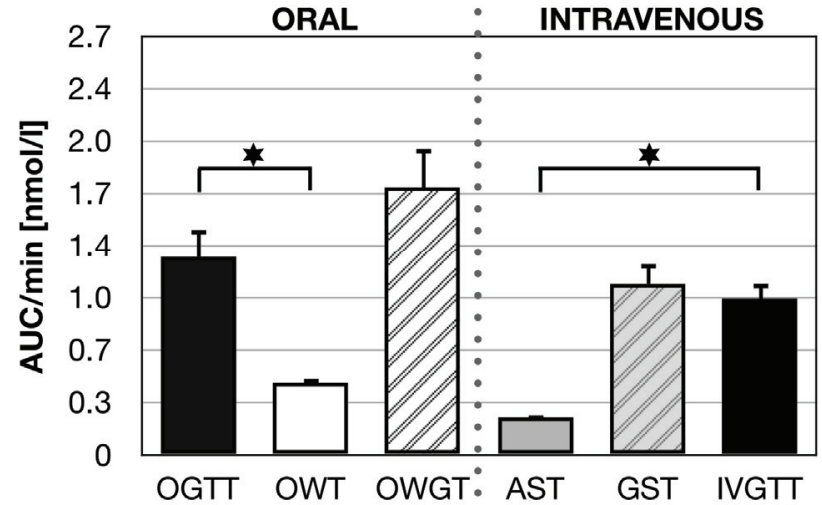

Fig. 3. Mean ( \pm SEM) incremental areas under the curve per minute (iAUC/min) for serum C-peptide concentration for all tests in healthy subjects $(n=8)$. Values from OGTT (black) were taken as a reference for orally administered tests - for intravenous tests the reference was IVGTT values (black). * indicates values significantly different from reference $(p<0.05)$.

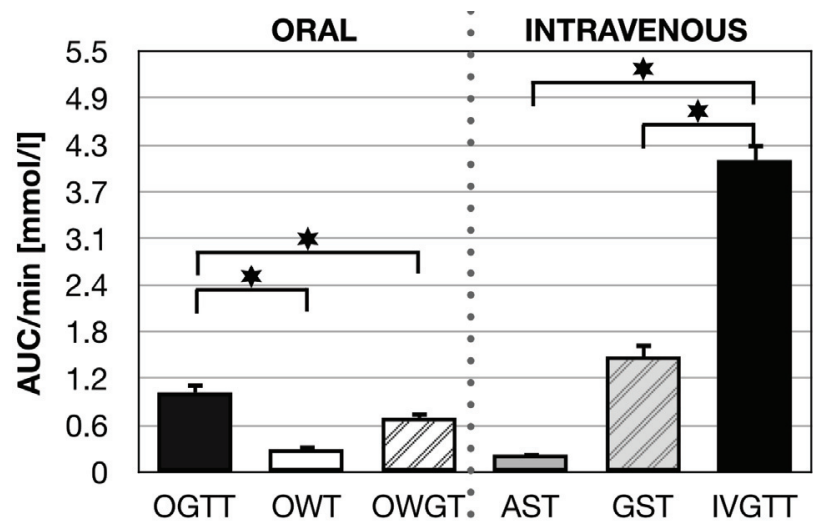

Fig. 4. Mean ( \pm SEM) $i A U C / m i n$ for plasma glucose concentration for all tests in healthy subjects $(n=8)$. Values from OGTT (black) were taken as a reference for orally administered tests - for intravenous tests, the reference was IVGTT values (black). * indicates values significantly different from the reference $(p<0.05)$.

OGTT (reference) as well as in case of OWGT. For the intravenous tests, the iAUC/min was $76 \%$ lower $(p<0.05)$ for the AST and $9 \%$ higher for the GST compared to IVGTT (reference). When comparing AST and OWT, OWT resulted in an $\mathrm{AAUC} / \mathrm{min}$ value that was $93 \%$ higher than AST.

\section{iAUC/min-glucose response (Fig. 4)}

Average glucose iAUC/min was (mean $\pm \mathrm{SEM}$ ) $1.04 \pm 0.13 \mathrm{mmol} / 1$ and $4.08 \pm 0.22 \mathrm{mmol} / \mathrm{l}$ for OGTT and IVGTT, respectively. OWT induced an $\mathrm{iAUC} / \mathrm{min}$ value $71 \%$ lower $(\mathrm{p}<0.05)$ than oral OGTT (reference), a similar situation was also true for OWGT, which reached an $\mathrm{iAUC} / \mathrm{min}$ value that was $32 \%$ lower $(\mathrm{p}<0.05)$. Relative to the intravenous tests, the iAUC/min was 
lower for both the AST $(94 \% ; p<0.05)$ and GST $(63 \%$; $\mathrm{p}<0.05$ ) compared to IVGTT (reference).

\section{Test tolerance by participants}

OGTT caused intermittent nausea in $25 \%$ of participants and $50 \%$ of participants experienced tachycardia during IVGTT. GST caused intermittent nausea, tachycardia and tachypnea in $100 \%$ of participants. OWT, OWGT and AST produced no observed side effects.

\section{Discussion}

The results of this study showed that acute oral administration of whey proteins alone and in combination with glucose in healthy participants leads to an increase in total serum C-peptide concentration. These results were comparable with results of other methods often used for the assessment of normal C-peptide secretory responses to oral and intravenous stimuli. The advantage of using these tests is that they allow accurate characterization of both fasting and stimulated C-peptide concentrations and are thus able to detect (early) a progressive loss of function of pancreatic islet beta cells and the subsequent decrease in the maximal capacity of C-peptide secretion. This is important since changes in stimulated C-peptide levels are more obvious that changes in fasting C-peptide levels. The decrease of C-peptide secretion capacity rapidly leads to development of glucose intolerance, caused by an inadequate increase in insulin secretion in relation to insulin resistance (Ahrén and Larsson 2002). Therefore early discovery of C-peptide secretion impairment could be of an importance for the timely introduction of preventive and therapeutic interventions. Faerch et al. (2009) reported that impairment usually starts several years before it is possible to classify individuals as abnormally hyperglycemic either in the fasting or post-challenge state.

A consistent increase in the total C-peptide concentration (iAUC/min) was perceived in case of OWT, while postprandial plasma glucose level remained almost unchanged in comparison with the other tests (with the exception of the AST). Our data shows, that after administering $40 \mathrm{~g}$ of pure whey proteins (i.e. performing OWT), the iAUC/min for postprandial plasma glucose level $(0.30 \mathrm{mmol} / \mathrm{l})$ was comparable with the iAUC/min after intravenous administration of $5 \mathrm{~g}$ arginine $(0.23 \mathrm{mmol} / \mathrm{l})$, which is an important feature of non-hyperglycemic tests that evaluate glucose mechanisms in individuals with glucose tolerance disorders. However, we observed different values for the iAUC/min C-peptide response. Whey proteins alone stimulated C-peptide secretion to a higher $\mathrm{iAUC} / \mathrm{min}$ $(0.46 \mathrm{nmol} / \mathrm{l} ; \mathrm{p}<0.05)$ than arginine $(0.24 \mathrm{nmol} / \mathrm{l})$.

Whey proteins alone are therefore able to increase C-peptide secretion more than the stimulated plasma glucose level indicates which is consistent with the findings of Nilsson et al. (2004). Nilsson et al. (2004) further demonstrated that the major reason for the C-peptide secretion increase seems to be the activation of incretin hormones (glucose-dependent insulinotropic polypeptide (GIP), and glucagon-like peptide-1 (GLP-1); together with the actual rise of plasma amino acid concentrations (especially BCAA), that could have a direct effect on insulin secretion of beta-cells.

Results of this study also showed that whey proteins administered in combination with glucose (as in case of OWGT) stimulated the highest $\mathrm{iAUC} / \mathrm{min}$ C-peptide response of all tests. OWGT thus preferentially assessed the total C-peptide response of all tests in healthy individuals, while the $\mathrm{iAUC} / \mathrm{min}$ of glucose concentrations were significantly reduced compared with results using an equivalent amount of glucose. Decreases in plasma glucose concentrations associated with OWGT are a direct physiological consequence of hyperinsulinemia (Floyd et al. 1963), which causes the consumption of glucose in peripheral tissues and reduction of endogenous glycogenolysis, resulting in increased glycogen concentrations to avoid hypoglycemia (Gannon and Nutall 2010).

In summary, we examined the properties of whey proteins as a C-peptide secretagogue using established C-peptide stimulation tests. Whey proteins alone consistently increased total C-peptide concentration, without increasing postprandial plasma glucose levels. Forty grams of whey proteins combined with $72.6 \mathrm{~g}$ of glucose induced total C-peptide secretion that was $36 \%$ higher than an equivalent amount of glucose, while maintaining significantly lower levels of plasma glucose. Results of this study suggest that both dietology and C-peptide secretion testing might take advantage of the unique property of whey proteins.

\section{Conflict of Interest}

Elena Wildová, Pavel Dlouhý, Jolana Rambousková and Michal Anděl cooperate with MILCOM company and Bohušovická mlékárna on different types of research. 
This collaboration is granted by research grants. Michal Anděl developed several formulas for enteral nutrition, which are produced by Bohušovická mlékárna. Michal Anděl and Pavel Dlouhý also published the booklets on medical aspects of milk, printed by Potravinářská komora České republiky.

\section{Acknowledgements}

The study was supported by the National Agency for Agricultural Research (grant NAZV 101B090) and was conducted in cooperation with MILCOM company. The authors are grateful to those participating in the study and Ms. Diana Mžyková for her expert technical assistance. The authors would also like to thank Ing. Petr Nováček and Ing. Jiří Wild for statistical analysis and advice on the statistical presentation, Doc. Petr Tůma for amino acid analysis of whey proteins concentrate and Thomas Secrest for language editing of the English version of this study.

\section{References}

AHRÉN B, LARSSON H: Quantification of insulin secretion in relation to insulin sensitivity in nondiabetic postmenopausal women. Diabetes 51: 202-211, 2002.

AKHAVAN T, LUHOVYY BL, BROWN PH, CHO CE, ANDERSON GH: Effect of premeal consumption of whey protein and its hydrolysate on food intake and postmeal glycemia and insulin responses in young adults. Am J Clin Nutr 91: 966-975, 2010.

CHAILlOUS L, ROHMER V, MAUGENDRE D, LECOMTE P, MARÉCHAUD R, MARRE M, GUILHEM I, CHARBONNEL B, SAÏ P: Differential beta-cell response to glucose, glucagon, and arginine during progression to type I (insulin-dependent) diabetes mellitus. Metabolism 45: 306-314, 1996.

FAERCH K, BORCH-JOHNSEN K, HOLST JJ, VAAG A: Pathophysiology and aetiology of impaired fasting glycaemia and impaired glucose tolerance: does it matter for prevention and treatment of type 2 diabetes? Diabetologia 52: 1714-1723, 2009.

FLOYD JC JR, FAJANS SS, KNOPF RF, CONN JW: Evidence that insulin release is the mechanism for experimentally induced leucine hypoglycemia in man. J Clin Invest 42: 1714-1719, 1963.

FLOYD JC JR, FAJANS SS, CONN JW, KNOPF RF, RULL J: Insulin secretion in response to protein ingestion. J Clin Invest 45: 1479-1486, 1966.

GANNON MC, NUTTALL FQ: Amino acid ingestion and glucose metabolism - a review. IUBMB Life 62: 660-668, 2010.

GENUTH S, ALBERTI KG, BENETT P, BUSE J, DEFRONZO R, KAHN R, KITZMILLER J, KNOWLER WC, LEBOVITZ H, LERNMARK A, NATHAN D, PALMER J, RIZZA R, SAUDEK C, SHAW J, STEFFES M, STERN M, TUOMILEHTO J, ZIMMET P: Expert Committee on the Diagnosis and Classification of Diabetes Mellitus: Follow-up report on the diagnosis of diabetes mellitus. Diabetes Care 26: 3160-3167, 2003.

GOTTSÄTER A, LANDIN-OLSSON M, FERNLUND P, GULLBERG B, LERNMARK A, SUNDKVIST G: Pancreatic beta-cell function evaluated by intravenous glucose and glucagon stimulation. A comparison between insulin and C-peptide to measure insulin secretion. Scand J Clin Lab Invest 52: 631-639, 1992.

GREENBAUM CJ, MANDRUP-POULSEN T, MCGEE PF, BATTELINO T, HAASTERT B, LUDVIGSSON J, POZZILLI P, LACHIN JM, KOLB H, TYPE 1 DIABETES TRIAL NET RESEARCH GROUP; EUROPEAN C-PEPTIDE TRIAL STUDY GROUP: Mixed-meal tolerance test versus glucagon stimulation test for the assessment of beta-cell function in therapeutic trials in type 1 diabetes. Diabetes Care 31: 1966-1971, 2008.

KAO PC, TAYLOR RL, HESER DW: C-peptide immunochemiluminometric assay developed from two seemingly identical polyclonal antisera. Ann Clin Lab Sci 22: 307-316, 1992.

KREZOWSKI PA, NUTTALL FQ, GANNON MC, BARTOSH NH: The effect of protein ingestion on the metabolic response to oral glucose in normal individuals. Am J Clin Nutr 44: 847-856, 1986.

MARI A, PACINI G, MURPHY E, LUDVIK B, NOLAN JJ: A model-based method for assessing insulin sensitivity from the oral glucose tolerance test. Diabetes Care 24: 539-548, 2001. 
MATTHEWS DR, HOSKER JP, RUDENSKI AS, NAYLOR BA, TREACHER DF, TURNER RC: Homeostasis model assessment: insulin resistance and beta-cell function from fasting plasma glucose and insulin concentrations in man. Diabetologia 28: 412-419, 1985.

NILSSON M, STENBERG M, FRID AH, HOLST JJ, BJÖRCK IM: Glycemia and insulinemia in healthy subjects after lactose-equivalent meals of milk and other food proteins: the role of plasma amino acids and incretins. Am J Clin Nutr 80: 1246-1253, 2004.

PAL S, ELLIS V: The acute effects of four protein meals on insulin, glucose, appetite and energy intake in lean men. $\mathrm{Br}$ J Nutr 104: 1241-1248, 2010.

PASSEY RB, GILLUM RL, FULLER JB, URRY FM, GILES ML: Evaluation and comparison of 10 glucose methods and the reference method recommended in the proposed product class standard (1974). Clin Chem 23: 131139, 1977.

POLONSKY KS, RUBENSTEIN AH: C-peptide as a measure of the secretion and hepatic extraction of insulin. Pitfalls and limitations. Diabetes 33: 486-494, 1984.

POLONSKY KS, GIVEN BD, VAN CAUTER E: Twenty-four-hour profiles and pulsatile patterns of insulin secretion in normal and obese subjects. J Clin Invest 81: 442-448, 1988.

SMALL M, COHEN HN, BEASTALL GH, MACCUISH AC: Comparison of oral glucose loading and intravenous glucagon injection as stimuli to C-peptide secretion in normal men. Diabet Med 2: 181-183, 1985.

VERRILL S, JOHNSON RA: Confidence bounds and hypothesis tests for normal distribution coefficients of variation. Commun Stat Theory Methods 36: 2187-2206, 2007.

WARD WK, BOLGIANO DC, MCKNIGHT B, HALTER JB, PORTE D JR: Diminished B cell secretory capacity in patients with noninsulin-dependent diabetes mellitus. J Clin Invest 74: 1318-1328, 1984. 